\title{
MASTERING
}

\section{BUSINESS COMMUNICATION}


Accounting

Accounting Skills

Advanced English Language

Advanced English Literature

Advanced Pure Mathematics

Arabic

Basic Management

Biology

British Politics

Business Communication

Business Environment

C Programming

$\mathrm{C}++$ Programming

Chemistry

COBOL Programming

Communication

Computing

Counselling Skills

Counselling Theory

Customer Relations

Database Design

Delphi Programming

Desktop Publishing

Economic and Social History

Economics

Electrical Engineering

Electronics

Employee Development

English Grammar

English Language

English Literature

Fashion Buying and Merchandising

Management

Fashion Styling

French

Geography

German
Global Information Systems

Human Resource Management

Information Technology

International Trade

Internet

Italian

Java

Management Skills

Marketing Management

Mathematics

Microsoft Office

Microsoft Windows, Novell

NetWare and UNIX

Modern British History

Modern European History

Modern United States History

Modern World History

Networks

Novels of Jane Austen

Organisational Behaviour

Pascal and Delphi Programming

Philosophy

Physics

Practical Criticism

Psychology

Shakespeare

Social Welfare

Sociology

Spanish

Statistics

Strategic Management

Systems Analysis and Design

Team Leadership

Theology

Twentieth Century Russian History

Visual Basic

World Religions

www.palgravemasterseries.com

\section{Palgrave Master Series}

\section{Series Standing Ordar ISBN 978-0-333-69343-8}

(outside North America only)

You can receive future titles in this series as they are published by placing a standing order. Please contact your bookseller or, in case of difficulty, write to us at the address below with your name and address, the title of the series and the ISBN quoted above.

Customer Services Department, Macmillan Distribution Ltd

Houndmills, Basingstoke, Hampshire RG21 6XS, England 


\section{MASTERING}

\section{BUSLIESS COMMUNICATION}

L.A. WOOLCOTT

AND

W.R. UNWIN 


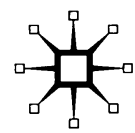

Text 10 Lysbeth A. Woolcott and Wendy R. Unwin 1983

(C) Illustrations: Barry Jackson 1983

(C) Text figures: Macmillan Press Ltd

All rights reserved. No reproduction, copy or transmission of this publication may be made without written permission.

No paragraph of this publication may be reproduced, copied or transmitted save with written permission or in accordance with the provisions of the Copyright, Designs and Patents Act 1988, or under the terms of any licence permitting limited copying issued by the Copyright Licensing Agency, 90 Tottenham Court Road, London W1P OLP.

Any person who does any unauthorised act in relation to this publication may be liable to criminal prosecution and civil claims for damages.

The authors have asserted their rights to be identified as the authors of this work in accordance with the Copyright, Designs and Patents Act 1988.

Published by

PALGRAVE

Houndmills, Basingstoke, Hampshire RG21 6XS and 175 Fifth Avenue, New York, N. Y. 10010

Companies and representatives throughout the world

PALGRAVE is the new global academic imprint of

St. Martin's Press LLC Scholarly and Reference Division and

Palgrave Publishers Ltd (formerly Macmillan Press Ltd).

ISBN 978-0-333-33529-1

ISBN 978-1-349-17180-4 (eBook)

DOI 10.1007/978-1-349-17180-4

This book is printed on paper suitable for recycling and made from fully managed and sustained forest sources.

A catalogue record for this book is available from the British Library.

$\begin{array}{lllll}19 & 18 & 17 & 16 & 15\end{array}$

$\begin{array}{lllllll}09 & 08 & 07 & 06 & 05 & 04 & 03\end{array}$ 


\section{CONTENTS}

Illustrations

Introduction

1 CORRESPONDENCE

Letters; memoranda; assignments

2 REPORTS

Varieties of report; compiling a report; summary; terms of reference; procedure; collection of information; questions to be asked; recording the information; analysis of the findings; searching for solutions; conclusions and recommendations; illustrations; appendices; writing the report; revision and editing; example of a report and report summary; assignments

3 SUMMARISING

Uses of summarising techniques; note-making; brief summaries; longer summaries; assignments

4 ADVERTISING AND PUBLICITY

Direct advertising; classified advertisements; display classified advertisements; display advertisements; content and style of advertisements; direct mail advertising; radio and television; press releases; articles; assignments

\section{MANUALS, INSTRUCTIONS AND FORM DESIGN}

Booklets and handbooks; procedure manuals; instructions for equipment use; job instructors' manuals; written instructions; form design; assignments

6 MEETINGS DOCUMENTATION

Notice of meeting; agenda; agenda papers; chairman's agenda; recording meetings; writing up minutes; the minute book; writing meetings reports; assignments 
7 MEETINGS

The main types of meetings; rules governing meetings; what the rules cover; general procedure; procedures and conventions; chairmanship; the role of the secretary; committee members; presenting a case; speeches and lectures; the art of acting; preparing the speech; visual aids; delivery; stance; answering questions; assignments

8 SPOKEN COMMUNICATION

Telephone techniques; dictating; interviews; selection interviews; interview techniques; assessment; applying for employment; other interviews; appraisal; reward review; counselling; grievances; reprimands; dismissal; termination; the effectiveness of interviews; radio and television interviews; assignments

9 LISTENING AND READING

Listening; reading; assignments

10 THE ROLE OF AUdIO-VISUAL AIDS

Choosing your media; basic techniques; the media; assignments

11 THINKING AND PLANNING

The thinking process; thinking techniques, developing reasoning; considering the recipient; planning; sample plans; assignments

\section{LANGUAGE}

The wrong words; emotive language; too many words; the Fog Index; the right words; style and tone, sentence structure; paragraph structure; reference books; assignments

13 NON-VERBAL COMMUNICATION

The nature of non-verbal communication; behaviour patterns; the effect on spoken communication; assignments

\section{CHARTS AND GRAPHS}

Tables; line graphs; supply and demand curves; the $\mathrm{ABC}$ or Pareto curve, breakeven charts; $Z$ charts; bar or block charts; Gantt charts; histograms; frequency polygons; pie charts; pictograms; cartograms; scatter diagrams; activity charts and flow charts; decision tables and algorithms; organisation charts; assignments 
15 ANALYSIS AND INTERPRETATION

Applications at work; effective approaches; examination questions; the nature of comprehension questions; method; general advice; types of questions; assignments

16 EXTERNAL AND INTERNAL COMMUNICATION

External communication; contact with the public; internal communication; assignments

17 MANAGEMENT COMMUNICATION

The need to improve; structure and lines of communication; the place of informal communication; the choice of media; the effect of communication on human interaction; assignments

18. INFORMATION TECHNOLOGY - THE FUTURE

The technological developments already in use; developments foreseeable this century; the effect on the process of communication; the effect of advanced technology on communication; assignments

Appendix 1: Answers/notes for answers

Appendix 2: Glossary of meetings terms

Appendix 3: Grammar, punctuation and spelling 
1.1 An unnecessary letter 4

1.2 A semi-blocked letter 5

1.3 A fully blocked letter 6

$\begin{array}{lll}1.4 & \text { A badly planned letter } & 10\end{array}$

1.5 Good planning and display 11

$\begin{array}{lll}1.6 & \text { A pompous letter } & 12\end{array}$

$\begin{array}{lll}1.7 & \text { A helpful letter } & 12\end{array}$

$\begin{array}{lll}1.8 & \text { Good intentions! } & 13\end{array}$

$\begin{array}{lll}1.9 & \text { Style and tone } & 13\end{array}$

$\begin{array}{ll}1.10 \text { A standard letter } & 15\end{array}$

$\begin{array}{lll}1.11 \text { A letter of complaint } & 16\end{array}$

$\begin{array}{lll}1.12 & \text { A letter seeking redress } & 17\end{array}$

$\begin{array}{lll}1.13 \text { A letter of adjustment } & 18\end{array}$

$\begin{array}{lll}1.14 & \text { A letter of condolence } & 18\end{array}$

$\begin{array}{ll}1.15 & \text { Memo formats } \\ 2.1\end{array}$

2.1 Progress report 26

2.2 Methods of investigation 29

3.1 Telephone message form 50

$\begin{array}{lll}3.2 & \text { From letter to telex } & 51\end{array}$

4.1 Display classified advertisement 66

$\begin{array}{lll}4.2 & \text { Display advertisement } & 68\end{array}$

4.3 Display advertisement $\quad 69$

$\begin{array}{lll}4.4 & \text { Short display advertisement } & 70\end{array}$

$\begin{array}{lll}4.5 & \text { Sales letter } & 71\end{array}$

$\begin{array}{lll}4.6 & \text { Press release } & 73\end{array}$

$\begin{array}{lll}5.1 & \text { Brighten up your booklet } & 82\end{array}$

$\begin{array}{lll}5.2 & \text { Extract from procedure handbook } & 83\end{array}$

$\begin{array}{lll}5.3 & \text { Extract from job-application form } & 87\end{array}$

$\begin{array}{lll}5.4 & \text { Extract from ambiguous form } & 87\end{array}$

6.1 Notice of meeting - informal 91

6.2 Notice of meeting - formal 92

6.3 Designing an agenda 94

6.4 A chairman's agenda 95

$\begin{array}{lll}6.5 & \text { Minutes } & 97\end{array}$

$\begin{array}{lll}7.1 & \text { From motion to resolution } & 111\end{array}$

$\begin{array}{lll}7.2 & \text { The board of Noah's Ark meets } & 117\end{array}$

$\begin{array}{lll}7.3 & \text { Presenting a case } & 119\end{array}$

$\begin{array}{lll}8.1 & \text { Job specification } & 131\end{array}$ 
$\begin{array}{lll}\text { 8.2 The stress interview } & 134\end{array}$

$\begin{array}{lll}8.3 & 136\end{array}$

10.1 Audio-visual aids? 154

$\begin{array}{lll}13.1 & 189\end{array}$

$\begin{array}{lll}13.2 & \text { Personal space } & 190\end{array}$

$\begin{array}{ll}14.1 & 195\end{array}$

\begin{tabular}{ll}
14.2 & Problems of perception \\
\hline
\end{tabular}

$\begin{array}{lll}14.3 & \text { Representation and misrepresentation } & 197\end{array}$

14.4 The Cold War (a non-quantitative line graph) 197

$\begin{array}{lll}14.5 & \text { A statistical table } & 198\end{array}$

14.6 A complex line graph 199

14.7 A complex line graph with index scale 201

$\begin{array}{lll}14.8 & \text { A straight-line graph } & 202\end{array}$

$\begin{array}{lll}14.9 & \text { A supply/demand curve } & 202\end{array}$

$\begin{array}{lll}14.10 & \mathrm{ABC} / \text { Pareto curve } & 203\end{array}$

$\begin{array}{lll}14.11 & \text { Breakeven chart } & 204\end{array}$

$\begin{array}{lll}14.12 & \text { A Z chart } & 205\end{array}$

14.13 A simple vertical bar chart 206

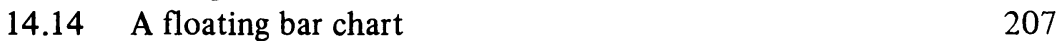

14.15 A horizontal bar chart 208

$\begin{array}{lll}14.16 & \text { Gantt chart } & 208\end{array}$

14.17 A histogram with equal frequency distribution 209

14.18 A histogram with unequal frequency distribution 210

$\begin{array}{ll}14.19 \text { A frequency polygon } & 211\end{array}$

$\begin{array}{ll}14.20 \text { A pie chart } & 212\end{array}$

$\begin{array}{lll}14.21 \text { A pictogram } & 212\end{array}$

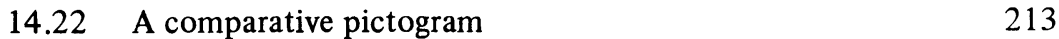

$\begin{array}{lll}14.23 & \text { A cartogram } & 214\end{array}$

$\begin{array}{lll}14.24 & \text { A scatter diagram } & 215\end{array}$

$\begin{array}{lll}14.25 & \text { Types of correlation } & 216\end{array}$

\begin{tabular}{ll}
14.26 & Paperwork flow chart \\
\hline
\end{tabular}

$\begin{array}{ll}14.27 \text { A flow chart } & 218\end{array}$

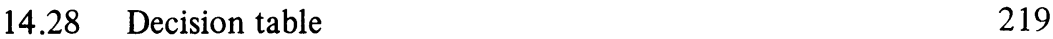

$\begin{array}{ll}14.29 \text { An algorithm } & 220\end{array}$

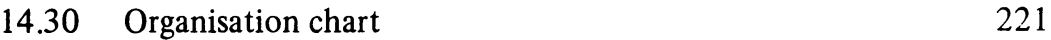

$\begin{array}{lll}14.31 & \text { A flow chart } & 223\end{array}$

14.32 Public information symbols 224

15.1 Consumers' expenditure on alcoholic drink 236

17.1 Section of a line and staff organisation chart 254

$\begin{array}{lll}17.2 & \text { Lines of communication } 255\end{array}$

18.1 The impact of information technology 269 